\title{
e-Government and e-Democracy: In Relation with Participation Cost Case study Central Java Provincial Government
}

\author{
Mustika Anggraeni ${ }^{12}$ \\ ${ }^{I}$ Department of Geography, Planning and International Development Studies, Faculty of Social and Behavioural Science, \\ Amsterdam Institute of Social Science Research, University of Amsterdam, Nieuw Acthtergracth 166, 1018 WV Amsterdam, \\ The Netherlands \\ ${ }^{2}$ Urban and Regional Planning, Engineering Faculty, Brawijaya University, MT. Haryono 16765145 Malang, Indonesia
} M.Anggraeni@uva.nl

Keywords: Participation cost, e-government, e-democratic, stakeholders' participation

Abstract: The aim of this research is (1) what can be learned from the literature about e-government, e-democracy and how the cost has been problematized; (2) the status of e-government/e-democracy level in Central Java Provincial Government. And (3) how is the participation cost being discussed in Central Java Provincial Government. A case study is the main approach in this research, as well as in-depth interview and literature review. The result of this research area (1) E-government and e-democracy cannot be separated. Robust egovernment as the foundation of e-democracy. E-government sees as an efficient way to accommodate participation concepts in development because it eliminates spatial distance, time and other direct costs. The discussion of e-government cost remains lack of literature. (2) Central Java Provincial Government considered as a fair developed system of e-government (not yet e-democracy) comparing to other provinces in Indonesia. The political will of the leader is strong to encourage the transformation of e-governance to edemocracy. Focus on the information source, and public services, and enable data gathering from the online platform. In term of building consensus, the e-government needs to be developed to achieve this objective of better democratization. (3) The expectation that the e-governance system will lead to efficient government is not always the case unless the ICT backed up with managerial preparedness to ensure participation. The cost of participation in e-government need to be borne by the government as investment and maintenance cost and borne by the participants, includes the connectivity gap.

\section{INTRODUCTION}

The fast-growing Information Communication Technology (ICT) influences the way government govern and manage the policy processes. ICT is a tool functioned as an enabler of e-government and edemocracy. E-government appears in the 90's that expected to improve the governance to be more democratic with the ICT (Roman \& Miller, 2013).

E-government also expected to increase government's legitimacy, transparency, and accountability. This also can act as a driver for bureaucratic transformation, which encourages wider public participation, to gain trust, public satisfaction on the quality of service, better structure, process and procedure of democracy. Last but not least, the e-government plays a role in the costsaving mechanism since e-government eliminates spatial distance, time and other direct and indirect cost.

E-government objective is in line with stakeholder's participation's goal to improve democratic governance. In Indonesia context, according to the Public Participation Act (Number $34,2014)$, the principle of participation needs to be accommodated in all level of decision making. The steps are planning, budgeting, implementation and monitoring and evaluation. This treaty also requires a mechanism that allows citizen participation in the public policy process.

In Indonesia e-government begun to grow as a national program right after the implementation of Presidential Instruction 3, 2003 about Policy and National Strategy on e-Government Development. And the progress of the implementation of this concept is relatively slow (Mansyur, 2017). In 2003 
there are $33 \%$ of local governments do not have websites or the websites not accessible, and the position in 2018 remains $12 \%$ that have the same condition (Yunita \& Aprianto, 2018).

As mentioned before the application of ICT or government body with a website doesn't mean that the principle of e-government is applied automatically. E-government needs to have informed function, and gathering feedback from the society, and also provide public service. Furthermore, ideal e-government should have interactive dialogue to build consensus on public policy or planning. This is the core aspect to achieve democratic governance (Roman \& Miller, 2013).

Participation motivation is influenced by the cost of participation. As if it is true that e-government has such cost-effectiveness character, would it be a factor that can influence the level of participation of stakeholders to certain e-government mechanism?

\section{METHODS}

This research organically reviewed (Petticrew \& Roberts, 2006) the literature in the SCOPUS database to understand the relation between egovernance, e-democracy and their connection with participation cost. The query searched for: "stakeholder participation", e-governance, edemocracy, "participation cost", efficiency and effectivity. A case study is selected for this research because this method allows the researcher to understand the empirical phenomena to construct theory (Yin, 2013). The case selected for this study is Central Java Provincial government, which has the most percentage of accessible government website (Yunita \& Aprianto, 2018). Furthermore, an in-depth interview is selected for this research to have a comprehensive understanding of the implementation of e-government, e-democracy and how it is budgeted. The interviewee selected for this research is the key person who has hands-on experience in formulating development policies, programs and projects in provincial level.

\subsection{Theory On E-Government Towards E-Democracy, And How Much It Costs?}

The model of e-government divided into four main phase; (1) web presence, (2) interaction, (3) transaction (4) transformation and (5) e-democracy with responsibility and ethical (Slamet, Hamdan, \&
Deraman, 2009). Meanwhile, e-democracy model defined by OECD as information step, consultation step, and active participation (OECD, 2003)

The e-democracy is a long-term objective of egovernment. The difference between both concepts; the scope of e-government mainly for achieving good governance principle, namely; increasing efficiency, effectivity, transparency, and accountability of the governance process. Meanwhile, the scope of e-democracy mainly on citizen participation in all stage of public decision making through electronic media. Therefore, egovernment and e-democracy should be performed integrated an interplay between two concepts.

\section{RESULTS AND DISCUSSIONS}

\subsection{Central Java Province Case Study: E-Government Or E-Democracy?}

Generally, Indonesia $88 \%$ local (city and regency government) and provincial developed website and accessible in 2018. The stage of e-government status is $62 \%$ on interaction stage (Yunita \& Aprianto, 2018). Interaction stage divined as when the government website development includes interactive tools and provide links to other government bodies (Slamet et al., 2009).

Specifically, in the Central Java e-government platform, from 36 government bodies, all of them are already apply the e-governance system (see Table 1).

Table 1 Stage of e-Government in Central Java Province

\begin{tabular}{|l|l|l|}
\hline $\begin{array}{c}\text { Total Local } \\
\text { Government } \\
\text { Body }\end{array}$ & \multicolumn{1}{|c|}{$\begin{array}{c}\text { Stage of e- } \\
\text { government } \\
\text { (Gartner, 2000) }\end{array}$} & Total \\
\hline 36 & Web presence & 2 \\
\cline { 2 - 3 } & Interaction & 15 \\
\cline { 2 - 3 } & Transaction & 17 \\
\cline { 2 - 3 } & Transformation & 2 \\
\hline
\end{tabular}

Source: (Yunita \& Aprianto, 2018)

According to the statistics, Central Java Province is well-improved compared to the national level, since $47 \%$ of government bodies are already in transaction stages of e-government. It means that the local government already establish online public service, and inter-operationalise it with other bodies (Slamet et al., 2009). Even two of the local government previously reach transformation stage which is developed public service application which integrates G2G (government to government), G2B 
(government to business), and G2C (Government to Community).

This positive result influenced by the political will of the leader to encourage stakeholder involvement into the governing process. As mentioned in an interview where the political will of the leader influence how the e-governance effectively developed in Central Java Province, such as by using the Governor's social media account as a tool to gain certain response from the societ (see Figure 1).

So far Central Java made notable progress on the provision of information and public service. However, to reach democratic governance, it needs to enable dialogue among stakeholders in the eplatform (Roman \& Miller, 2013). An interview stated that in the cycle of program and projects, always need a room for consensus building, but in case of online platform might find difficulties. Since the website and social media are dominantly to compile the complaints and feedbacks of the society, and they take action quite fast on this.

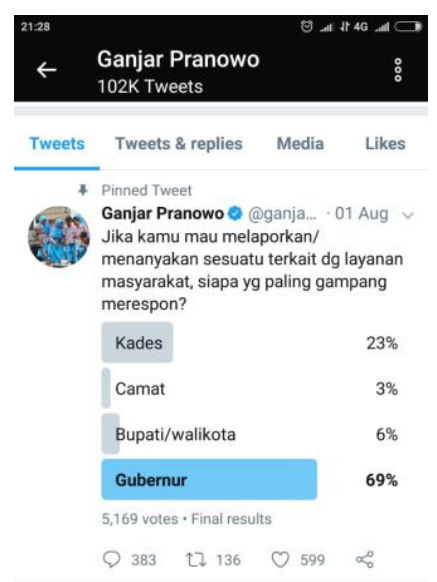

Figure 1 accessed 18/8/2018, sent by the interviewee

Based on the interview and observation on the websites, confirmed that Central Java Provincial egovernment still focussed on the provision of public service. This also influences the Indonesian Democratic Index (IDI) for Central Java is 70,85 categorized as "fair" slightly above the national average (BPS, 2018).

Also, the decision and action in which government react to the feedback of society remain in an executive driven and "managerial" model of interaction between government and stakeholders. This is in line with a theory that democratic potential such as consultative or dialogue for e-government is often marginalized (Chadwick \& May, 2003).
Other factors that influence the success of egovernment is participation. Participation will happen if there is the capacity of stakeholders, willingness and opportunity to participate. For example, in Boyolali e-government platform, overall participation of stakeholder to support egovernment, opportunity to participate and willingness to participate is fair. Meanwhile, it is still lack of the ability to participate. (Putra, 2017). Here we can conclude that capacity building for participation in e-government is needed to be properly planned. Furthermore, the willingness to participate in a program influenced by the cost of participation, as elaborated in next section.

\subsection{Consideration Of The Participation Cost In E-Government's System In Central Java Province}

Cost is an important factor of a successful egovernment and furthermore e-democracy. To provide such an interactive platform surely need investment commitment from the government and also from stakeholders. This also challenges the argument that the ICT is more cost efficient than the conventional way.

From the government's perspective, the development of e-government platform since 2003 is an expensive investment. As mentioned (Fountain, 2008), the highest percentage of the cost is for an external IT consultant to build the platform. However, in Indonesia, the cost of internet broadband is relatively high. e-government is not as simple as providing the facility and develop a website. It should be cost-efficient compared to conventional means, nonetheless, it is not automatically cost efficient. Successful egovernment need to be backed up with proper planning also an adequate and commitment to provide resources to support the e-government to be sustained (Roman \& Miller, 2013). To conduct these efforts, budget support is essential, and need the political will to support this.

Cost of participation in Central Java Province from the previous research has difficult start to provide investment to e-government infrastructure (Suparno, 2011). Moreover, this investment needs to be followed by maintenance cost and assurance of internet access. A sample from Surakarta which is one of the cities that reach transformation stage of egovernment, in $20170,67 \%$ of total budget is dedicated to support the e-government, most of the 
cost element covered the connectivity gap and web maintenance.

In the other side, the cost of participation in egovernment needs to be borne by the participant. The participation quality and quantity are influenced by the cost of participation (Wang \& Bryer, 2013). The element of cost from the participant's side is the connectivity gap due to capacity to ICT, and cost of internet access. Aligned with the experience of Boyolali (Putra, 2017), that the ability of society to access e-government is not equally distributed in Central Java, depends on education and economic characteristic of each regency and city in Central Java.

\section{CONCLUSIONS}

E-government and e-democracy cannot be separated. The fact that e-government become the foundation of e-democracy. E-government sees as an efficient way to accommodate participation concepts in development because it eliminates spatial distance, time and other direct costs. The discussion of egovernment cost is still lack of literature.

Central Java Provincial Government considered as a well-developed system of e-government comparing to the other provinces in Indonesia. The political will of the leader is strong to encourage the transformation of e-governance to e-democracy. Focus on the information source, and public services, and enable data gathering from the online platform. In term of building conclusion, the egovernment needs to be developed to achieve this objective of better democratization.

The expectation that the e-governance system will lead to efficient government is not always the case unless the ICT backed up with managerial preparedness to ensure participation. The cost of participation in e-government need to be borne by the government as investment and maintenance cost and borne by the participants, includes the connectivity gap.

\section{REFERENCES}

BPS. (2018). Indeks Demokrasi Indonesia (IDI), 2017.

Chadwick, A., \& May, C. (2003). Interaction between states and citizens in the age of the Internet: "egovernment" in the United States, Britain, and the European Union. Governance, 16(2), 271-300. http://doi.org/10.1111/1468-0491.00216

Chugunov, A. V, Kabanov, Y., \& Misnikov, Y. (2017). Citizens versus the government or citizens with the government: A tale of two e-participation portals in one city - A case study of St. Petersburg, Russia. In ACM International Conference Proceeding Series (Vol. Part F128003, pp. 70-77). http://doi.org/10.1145/3047273.3047276

Fountain, J. (2008). Central Issues in the Political Development of the Virtual State. In M. Castells \& G. Cardoso (Eds.), The Network Society From Knowledge to Policy (1st ed., pp. 149-182). Massachusetts: Johns Hopkins Center for Transatlantic Relations.

Mansyur, F. (2017). e-Government Research in Indonesia: Systematic Literature Review from The Perspective of e-Government Ranking Dimension Indonesia (PeGI). IPTEK-KOM, 19(1).

OECD. (2003). Promise And Problems Of E-Democracy Challenges of Online Citizen Engagement. Retrieved from http://www.oecd.org/dataoecd/9/11/35176328.pdf

Petticrew, M., \& Roberts, H. (2006). Systematic Reviews in the Social Sciences: A Practical Guide. Blackwell Pub. Retrieved from https://books.google.nl/books?id=_Ly3aPhTkbkC

Putra, M. T. (2017). Evaluasi Partisipasi Masyarakat dalam e-Government Pelayanan Publik di Kabupaten Boyolali (Vol. 1).

Roman, A. V, \& Miller, H. T. (2013). New questions for e-government: Efficiency but not (yet?) democracy. International Journal of Electronic Government Research, 9(1), 65-81. http://doi.org/10.4018/jegr.2013010104

Slamet, Hamdan, A. R., \& Deraman, A. (2009). eDemocracy in Indonesia, between Opportunities and Spectacles of Phenomenology Approach. In Seminar Nasional Informatika (semnasIF). Yogyakarta.

Suparno. (2011). Kinerja Pemerintah Daerah: Akankah berbeda Setelah Penerapan E-Government? Mimbar Administrasi FISIP UNTAG Semarang, 5(8).

Wang, X. H., \& Bryer, T. A. (2013). Assessing the Costs of Public Participation: A Case Study of Two Online Participation Mechanisms. American Review of Public Administration, 43(2), 179-199. http://doi.org/10.1177/0275074012438727

Yin, R. K. (2013). Case Study Research (International Student Edition): Design and Methods. SAGE Publications. Retrieved from https://books.google.nl/books?id=EoqmmQEACAA J

Yunita, N. P., \& Aprianto, R. D. (2018). Kondisi Terkini Perkembangan Pelaksanaan E-Government di Indonesia: Analisis Website. In Seminar Nasional Teknologi Informasi dan Komunikasi (Vol. 2018, pp. 23-24). Yogyakarta. 